\title{
有限要素法による弾性板の音響入射に対する応答解析 VIBRO/ACOUSTIC ANALYSIS OF ELASTIC PLATES BY FINITE ELEMENT METHOD
}

\author{
大鶴 徹* \\ Toru OTSURU
}

\begin{abstract}
Here presented is a method to analyze the vibro/acoustic characteristics of plates with complex boundary conditions. The interaction between plate and air is taken into account in the form of radiation impedance. A matrix equation to compute the radiation impedance is set up through the finite elemental procedure with the help of the element selecting matrix. The transmitted sound pressure and the transmission loss can also be obtained by solving the matrix equation presented here. Several example computations on a plate showed good agreement between the values derived by this method and those by the classic analytical solutions.
\end{abstract}

Keywords : elastic plate, finite element method, acoustic radiation, sound transmission loss, specific radiation impedance

弾性板、有限要素法、音響放射、透過損失、比放射インピーダンス

\section{1. 序}

建筑空間で用いられる壁体は、通常、空間並びに支持 形態ともに単純とは言い難い。特に屈曲振動を行う弾性 板の振動及び音響放射性状は、単純支持等の円形板や矩 形板に関しては、古くから解析が行われているものの1 5)、形態が複雑な場合、詳細な解析は容易ではない。

筆者らは既報67788)で、無限大バッフル内に設置された 弾性壁体の透過損失に関する基䃈的研究の報告を行い、 有限要素法による弾性壁体の透過損失解析手法の基礎部 分を提示してきた（なおバッフルの振動やバッフルから の反射音の影響は、上記の諸研究と同様に、無視してい る）。筆者らのこの手法は、複雑な形態を有する弾性板 の解析へ適用可能な手法ではあるものの、簡単のため、 比放射インピーダンスを介したモードの連成を無視して いた。さらに、板振動と空気の連成を処理する際に重要 となる比放射インピーダンスは、他の解析方法で求めた 値を適用しており、有限要素解析の過程を利用したその
導出方法については触れていない。従って、モードの連 成まで考慮した弾性板の音響透過損失解析手法及び、弾 性板の比放射インピーダンスをマトリクス演算により効 率的に求める手法の開発は、筆者らの解析の完備化にと って重要な課題としていた。

一方、比放射インピーダンスを用いることなく、室空 気まで含めて有限要素解析を適用し、板振動と空気の連 成を求める方法も試みられ9)10)筆者らも一部検討してい る11)が、3 次元空間の有限要素分割に多くの自由度を必 要とする。さらに本研究においては、板の音響特性の解 明に焦点を絞る目的で、前述のように板は無限大バッフ ル内に設置され、その両側の空間は無限大と仮定してい る。従って、その有限要素解析には無限要素12)等の特殊 な要素の適用が必要となる。

また、無限空間への音響放射を含む問題については境 界要素法が適しており、近年、種々の研究が試みられ成 果をあ(゙ている12) 14)。しかし、阪上ら14)が「反射音場

\footnotetext{
$*$ 大分大学工学部建設工学科 助教授 $\cdot$ 工博

Assoc. Prof., Dept. of Architectural Engineering, Faculty of Engineering, Oita Univ., Dr. Eng.
} 
を解析するためには、板の弾性振動を考慮する必要があ る」と指摘するように、多自由度の共振系である有限大 弾性板を含んだ空間の解析には、板の振動方程式を解く ための配留が重要と思われる。

そこで本論文では、板の振動についてはモード解析法 で解を求め、各モードと空気の連成を比放射インピーダ ンスで処理する有限要素解析手法を提示する。即ち、上 記の設定の弾性板の音響入射に対する応答を、板要素の みを用いる有限要素法によりモードの連成を含めて求め る手法である。また、板の各モードに関する比放射イン ピーダンス算定式の導出も行う。これはモードベクトル として数値的に得られる情報を用い、マトリクス演算に より算定するものである。最後に、これらの手法をアル ミニウム板の透過損失解析へ適用し、解析解との比較等 から、その妥当性を明らかにする。

\section{貶号衰}

$A, B:$ 板の長さ[m]

$a, b$ : 板要素の要素長[m]

$c$ : 音速 $[\mathrm{m} / \mathrm{sec}]$

$E:$ 板のヤング率 $\left[\mathrm{kg} / \mathrm{m}^{3}\right]$

$h:$ 板厚 $[\mathrm{m}]$

$h_{n}: n$ 次の滅衰比

$i: \sqrt{-\Gamma}$

$k$ : 波長定数

$M_{n}: n$ 次の等価質量

$N$ : 離散系の総自由度数

$p_{i}$ ：入射音圧

$t$ : 時間

$z_{0}$ : 空気の特性インピーダンス $\left(=\rho_{0} c\right)$

$\eta$ : 板の損失係数

$\rho:$ 板の密度 $\left[\mathrm{kg} / \mathrm{m}^{3}\right]$

$\rho_{0}:$ 空気密度 $\left[\mathrm{kg} / \mathrm{m}^{3}\right]$

$\sigma:$ 板のポアソン比

$\omega:$ 外力の角周波数

$\omega_{n}: n$ 次の固有振動数

[ ],\{\}：マトリクス、ベクトル

$\mid F 、\left[\left.\right|^{1} ：\right.$ 転值及び逆行列

[C]：減衰マトリクス

$\{d\}$ ：節点変位ベクトル

$\{d\}_{\mathrm{e}}$ : 要素e $の$ 節点変位ベクトル

$\{F\}$ : 外力ベクトル（入射音圧ベクトル）

$[K]$ ：㓮性マトリクス

$[M]$ : 質量マトリクス

$\left\{\phi_{n}\right\}: n$ 次のモードベクトル

$\operatorname{Re}\{x\}: x$ の実部

$\operatorname{Im}\{x\}: x$ の虚部

$$
\begin{aligned}
& \dot{x}: \frac{\partial x}{\partial t} \\
& x^{*}: x \text { の共役複素数 }
\end{aligned}
$$

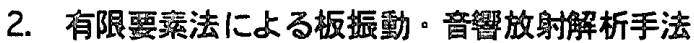

\section{1 問題設定と座標系}

本論の解析対象とする系を図1に、また、弾性板を有 限要素に分割した例とその座標系を図2に示す。以下の 解析では、簡単のため、密度や厚さ等が一様な板を仮定 した上で議論を展開している。なお板の周辺や内部の支 持条件は、用いる板要素の自由度を適宜固定する、ある いは梁要素等を組み合わせる、等により固定や単純支持、 自由端等、柔軟に対応できる。但し、既往の研究と同様、 板は無限大バッフル内に設置され、その両側は半無限大 空間とし、入射音や板と無限大バッフルの間の振動等の 相互作用は無視している。

\section{2 弾性板の振動解析}

弾性系の離散的連動方程式は、一般に次式で表わされ る13)。

$$
[M]\{\ddot{d}\}+[C]\{\dot{d}\}+[K]\{d\}=\{F\}
$$

減衰項が比例隇衰の形式を満たす場合、角周波数 $\omega の$ 調和外力に対するこの系の定常状態の応答は、モード解 析法により次式で求められる。

$$
\{d\}=\sum_{n=1}^{N} \alpha_{n}\left\{\phi_{n}\right\}
$$

但し、

$$
\begin{aligned}
& \alpha_{n}=\frac{\left\{\phi_{n}\right\}^{T}\{\bar{F}\} \mathrm{e}^{i \omega t}}{\left\{\left(\omega_{n}^{2}-\omega^{2}\right)+i 2 h_{n} \omega_{n} \omega\right\} M_{n}} \\
& M_{n}=\left\{\phi_{n}\right\}^{T}[M]\left\{\phi_{n}\right\}, \quad h_{n}=\frac{\left\{\phi_{n}\right\}^{T}[C]\left\{\phi_{n}\right\}}{2 \omega_{n} M_{n}} \\
& \{F\}=\{\bar{F}\} \mathrm{e}^{i \omega t}
\end{aligned}
$$

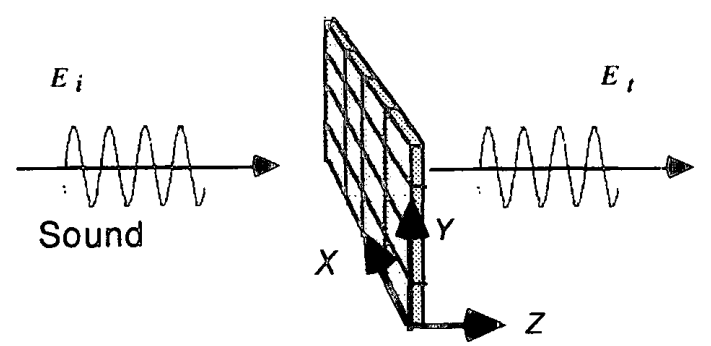

図 1 解析対象の弾性板と全体座標系、 板は無限大バッフル内に設置されている

$Y$

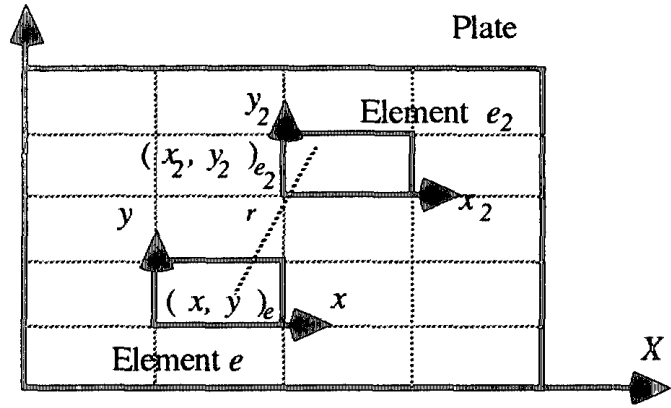

図 $2 Z=0$ 平面（板）上に設定した全体座標系 $(X, Y)$ 及び、要素 $e, e_{2}$ に関する局所座標系 $(x, y)_{e},\left(x_{2}, y_{2}\right)_{e 2}$ 
また $\left\{\phi_{n}\right\} と \omega_{n}$ は、(1)式に関する次のMK型固有值問題14) の解である。

$$
\left([K]-\omega^{2}[M]\right)\{\phi\}=\{0\} .
$$

\section{3 減衰項：板の内部損失と空気反力}

有限要素法では一般に、板曲げ要素e 内部の点 $(x, y)_{e}$ に 抢ける $z$ 方向変位 $w(x, y)_{e}$ を要素節点変位べクトル $\{d\}_{e}$ と $w$ に関する形状関数 $\left[N_{w}(x, y)_{e}\right]$ により次式のように近似す る。なお $\left[N_{w}(x, y)_{e}\right]$ は行べクトルである。また $(x, y)_{e}$ は要 素eに関する局所座標系であることを示す。

$$
w(x, y)_{e}=\left[N_{w}(x, y)_{e}\right]\{d\}_{e}
$$

ここで、系の隇衰を、板の内部損失と空気の反力（即 ち、音）の2者によるものとして次のように仮定する。

$$
[C]\{\dot{d}\}=\left[C_{p}\right]\{\dot{d}\}+\left[C_{a}\right]\{\dot{d}\}
$$

内部損失による減衰マトリクス $\left[C_{p}\right]$ は、構造隇衰として 次式で与える。

$$
\left[C_{p}\right]=\frac{\eta}{\omega}[K]
$$

一方、(8)式右辺の第 2 項は以下のように求められる。 まず、屈曲振動板の片側表面に生じる節点音圧べクトル $\left\{P_{t}\right\}$ 、比放射インピーダンスを用い、

$$
\left\{P_{t}\right\}=\sum_{m=1}^{N} \sum_{n=1}^{N} m \zeta_{n} z_{0} \dot{\alpha}_{m}\left\{\phi_{n}\right\}
$$

と表わす。音圧についてもwと同一の形状関数を適用す れば点 $(x, y)_{e}$ における音压 $p_{t}(x, y)_{e}$ は次式で得られる。

$$
p_{t}(x, y)_{e}=\left[N_{w}(x, y)_{e}\right]\left\{P_{t}\right\}_{e}
$$

なお既報8)では、モードの連成を無視し、以下、 $m={ }_{n}$ の 仮定の下で処理していた。

続いて、nモードの要素節点変位ベクトル、 $\alpha_{n}\left\{\phi_{n}\right\}_{e}$ を $\left\{d_{n}\right\}_{e}$ と記せば、要素に関する空気のなす仕事 $W_{e}$ は、板 両面の媒質が等しい場合、

$$
\begin{array}{r}
W_{e}=\{d\}_{e}^{T} \iint_{e}\left[N_{w}(x, y)_{e}\right]^{T}\left[N_{w}(x, y)_{e}\right] d x d y \times \\
\sum_{m}^{N} \sum_{n}^{N} 2 \zeta_{m}\left(\frac{\dot{\alpha_{m}}}{\dot{\alpha}_{n}}\right) z_{0}\left\{\dot{d_{n}}\right\}_{e} \\
=\{d\}_{e}^{T} \sum_{m}^{N} \sum_{n}^{N}\left[C_{a} m_{m, n}\right]_{e}\left\{\dot{d}_{n}\right\}_{e} \\
\text { 但し、 }\left[C_{a m, n}\right]_{e}=2{ }_{m} \zeta_{n}\left(\frac{\dot{\alpha_{m}}}{\dot{\alpha}_{n}}\right) z_{0} \frac{[M]_{e}}{\rho h}
\end{array}
$$

である。さらに、(12)式を板面全体へ拡張することによ って次式が成立する。

$$
\left[C_{a}\right]\{\dot{d}\}=\sum_{m} \sum_{n}\left[C_{a m, n}\right]\left\{\dot{d}_{n}\right\} \propto[M]
$$

即ち、上述の内部損失に関する仮定と合わせ、この系
の隇衰項が比例減衰の形式を満たすことが明らかとなっ た。これは、系の振動解析へ2.2のモード解析法を谪用す るための論理的基盤である。

以上によって(4)式の $h_{n}$ は、

$$
\begin{aligned}
h_{n} & =\frac{\left\{\phi_{n}\right\}^{T}\left(\left[C_{p}\right]+\left[C_{a n, n}\right]\right)\left\{\phi_{n}\right\}}{2 \omega_{n} M_{n}} \\
\therefore \quad & h_{n}=\frac{\eta \omega_{n}}{2 \omega}+\frac{n \zeta_{n} z_{0}}{\omega_{n} \rho h}
\end{aligned}
$$

となる。

このように本論の解析手法では、入射音圧については 外力ベクトルとして、反射及び透過音圧に関しては比放 射インピーダンスを利用した減衰マトリクス中で、それ ぞれ独立に処理し、以て、板振動のモード解析を可能と している。

\section{4 要素選定マトリクス}

以降の解析では、全体マトリクス (ベクトル) と要素 マトリクス（ベクトル）の変換を効率的かつ明確に行う 必要がある。この変換は、有限要素法の文献15) 17)では、 通常、暗㷛裏に行われている。一部の文献18)でブールマ トリクスの一種として特別な名称を付けずに、同様のマ トリクスを使用した例もあるが、これとは別個に筆者ら は、要素選定マトリクス(element selecting matrix) と称し て下式を満たすマトリクス $\left[S_{e}\right]$ 導入してきた19)。

$$
\begin{aligned}
\{d\}_{e} & =\left[S_{e}\right]\{d\} \\
{[M] } & =\sum_{e}\left[S_{e}\right]^{T}\left[M_{e}\left[S_{e}\right]\right.
\end{aligned}
$$

以下、この $\left[S_{e} \mid\right.$ を用いて議論を進める。

\section{5 放射音響パワー算定式}

屈曲振動板上の点 $(x, y)_{\mathrm{e}}$ から放射される単位面積あた りの音響パワー $\Pi(x, y)_{\mathrm{e}}$ は次式で与えられる。

$$
\begin{array}{r}
\Pi(x, y)_{e}=\frac{1}{2} \operatorname{Re}\left\{p_{t}(x, y)_{e} \cdot \dot{w}(x, y)_{e}{ }^{*}\right\} \\
=\frac{1}{2} \omega^{2} z_{0} \operatorname{Re}\left\{\left(\sum_{m=1}^{N} \sum_{n=1}^{N} m \zeta_{n} \alpha_{m}\left\{\phi_{n}\right\}_{e}{ }^{T}\right)\left[N_{w}(x, y)_{e}\right]^{T} \times\right. \\
\left.\left[N_{w}(x, y)_{e}\right]\left(\sum_{k=1}^{N} \alpha_{k}{ }^{*}\left\{\phi_{k}\right\}_{e}\right)\right\}
\end{array}
$$

従って、板面全体から板の片側空間へ放射される音響パ ワーE $E_{t}$ は次式で求められる。

$$
\begin{aligned}
& E_{l}=\sum_{e} \iint_{e} \Pi(x, y)_{e} d x d y \\
&=\sum_{e} \frac{1}{2} \omega^{2} z_{0} \operatorname{Re}\left\{\left(\sum_{m=1}^{N} \sum_{n=1}^{N} m \zeta_{n} \alpha_{m}\left\{\phi_{n}\right\}_{e}{ }^{T}\right) \times\right. \\
&\left.\left(\int_{e}\left[N_{w}(x, y)_{e}\right]^{T}\left[N_{w}(x, y)_{e}\right] d x d y\right)\left(\sum_{k=1}^{N} \alpha_{k}{ }^{*}\left\{\phi_{k}\right\}_{e}\right)\right\} \\
&=\sum_{e} \frac{1}{2} \omega^{2} z_{0} \operatorname{Re}\left\{\left(\sum_{m=1}^{N} \sum_{n=1}^{N} m \zeta_{n} \alpha_{m}\left\{\phi_{n}\right\}_{e}{ }^{T}\right) \times\right. \\
&\left.\frac{[M]_{e}}{\rho h}\left(\sum_{k=1}^{N} \alpha_{k}{ }^{*}\left\{\phi_{k}\right\}_{e}\right)\right\}
\end{aligned}
$$


さらにこの式は、 $\left|S_{e}\right|$ を利用して以下の通り変形できる。

$$
\begin{gathered}
E_{t}=\sum_{e} \frac{1}{2} \omega^{2} z_{0} \operatorname{Re}\left\{\left(\sum_{m=1}^{N} \sum_{n=1}^{N} m \zeta_{n} \alpha_{m}\left\{\phi_{n}\right\}^{T}\right) \times\right. \\
\left.\frac{\left[S_{e}\right]^{T}[M]_{e}\left[S_{e}\right]}{\rho h}\left(\sum_{k=1}^{N} \alpha_{k}^{*}\left\{\phi_{k}\right\}\right)\right\} \\
=\frac{1}{2} \omega^{2} z_{0} \operatorname{Re}\left\{\left(\sum_{m=1}^{N} \sum_{n=1}^{N} m \zeta_{n} \alpha_{m}\left\{\phi_{n}\right\}^{T}\right) \times\right. \\
\left.\frac{[M]}{\rho h}\left(\sum_{k=1}^{N} \alpha_{k}^{*}\left\{\phi_{k}\right\}\right)\right\}
\end{gathered}
$$

よって最終的に次式を得る。

$$
E_{t}=\frac{1}{2} \omega^{2} z_{0} \operatorname{Re}\left\{\sum_{m=1}^{N} \sum_{n=1}^{N} m \zeta_{n} \alpha_{m} \alpha_{n}^{*} \frac{M_{n}}{\rho h}\right\}
$$

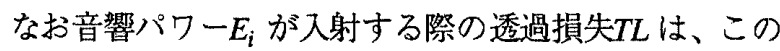
$E_{t}$ を透過側空間への放射音響パワーとみなすことにより、 次の通り算定できる。

$$
T L=-10 \log _{10} \frac{E_{t}}{E_{i}}
$$

\section{3. 比放射インピーダンス籍定式}

このように、比放射インピーダンス ${ }_{m} \zeta_{n}$ が何らかの方 法で求められている場合、弾性板からの放射音の音圧や 音響パワーが求められる。従って、上記の解析過程と整 合的な手法による $\zeta_{n}$ の導出が必要となる。そこで本章 では古典的手法1) 4)を基礎に、(6)式から離散的に得られ るモードベクトル $\left\{\phi_{m}\right\}$ と $\left\{\phi_{n}\right\} に$ 関する $\zeta_{m} \zeta_{n}$ のマトリクス 演算による算定式の導出を行う。

板面上の任意点、全体座標系で $(X, Y)$ ，局所座標系で、 ある要素 $e$ 内の $(x, y)_{\mathrm{e}}$ 、における板の面外方向変位成分 $w$ は、(2)(7)及び(17)式から、次のように表わされる。

$$
\begin{aligned}
w(X, Y) & =w(x, y)_{e}=\left[N_{w}(x, y)_{e}\right] \sum_{n=1}^{N} \alpha_{n}\left\{\phi_{n}\right\}_{e} \\
& =\left[N_{w}(x, y)_{e}\right]\left[S_{e}\right] \sum_{n=1}^{N} \alpha_{n}\left\{\phi_{n}\right\}
\end{aligned}
$$

この点（板の透過側表面）に生じる音圧 $p_{t}$ は、それぞれ ${ }_{m} \zeta_{n}$ 及びグリーン関数を用い、次の 2 式で表わすことが できる。なお $\left(X_{2}, Y_{2}\right)$ を局所座標系では $\left(x_{2} y_{2}\right)_{\mathrm{e}}$ と記す。

$$
\begin{aligned}
& p_{t}(X, Y)=p_{t}(x, y)_{e} \\
& \quad=i \omega \rho_{0} c\left[N_{w}(x, y)_{e}\right]\left[S_{e}\right] \sum_{n=1}^{N} \sum_{m=1}^{N}{ }_{m} \zeta_{n} \alpha_{m}\left\{\phi_{n}\right\}
\end{aligned}
$$

及び

$$
\begin{aligned}
p_{t}(X, Y) & =p_{t}(x, y)_{e} \\
= & \sum_{e_{2}} \frac{i^{2} \omega^{2} \rho_{0}}{2 \pi} \times \\
& \iint_{e_{2}}\left[N_{w}\left(x_{2}, y_{2}\right)_{e_{2}}\right]\left[S_{e_{2}}\right] \sum_{l=1}^{N} \alpha_{l}\left\{\phi_{l}\right\} \frac{\mathrm{e}^{-i k r}}{r} d x_{2} d y_{2}
\end{aligned}
$$

但し、

$$
r=\sqrt{\left(X-X_{2}\right)^{2}-\left(Y-Y_{2}\right)^{2}}
$$

なお上式に現われる 2 点 $(X, Y)$ 及び $\left(X_{2}, Y_{2}\right)$ を図 2 に例示し ている。この 2 式が成立する条件は、

$$
\begin{aligned}
i \omega \rho_{0} c\left[N_{w}(x, y)_{e}\right]\left[S_{e}\right] \sum_{n=1}^{N} m \zeta_{n} \alpha_{m}\left\{\phi_{n}\right\} \\
=\sum_{e_{2}} \frac{i^{2} \omega^{2} \rho_{0}}{2 \pi} \times \\
\quad \iint_{e_{2}}\left[N_{w}\left(x_{2}, y_{2}\right)_{e_{2}}\right]\left[S_{e_{2}}\right] \alpha_{m}\left\{\phi_{m}\right\} \frac{\mathrm{e}^{-i k r}}{r} d x_{2} d y_{2}
\end{aligned}
$$

である。ここでこの式の両辺に次の演算を施す。

$$
\sum_{e} \iint_{e}\left\{\left(\left[N_{w}(x, y)_{e}\right]\left[S_{e}\right]\left\{\phi_{n}\right\}\right)^{T} \times(E q .(27))\right\} d x d y
$$

この演算の結果をモードベクトルの直交性を利用して整 理すると、次のような比放射インピーダンスの算定式が 導出される。

$$
m \zeta_{n}=\frac{i k\left\{\phi_{n}\right\}^{T}\left[I_{1}\right]\left\{\phi_{m}\right\}}{2 \pi\left\{\phi_{n}\right\}^{T}\left[I_{2}\right]\left\{\phi_{n}\right\}}
$$

但し、

$$
\left[I_{1}\right]=\sum_{e} \sum_{e_{2}}\left[S_{e}\right]^{T} \iint_{e}\left[N_{w}(x, y)_{e}\right]^{T}\left[I_{e_{2}}\right]\left[S_{e_{2}}\right] d x d y
$$

また、

$$
\begin{aligned}
& {\left[I_{e_{2}}\right]=\iint_{e_{2}}\left[N_{w}\left(x_{2}, y_{2}\right)_{e_{2}}\right] \frac{\mathrm{e}^{-i k r}}{r} d x_{2} d y_{2}} \\
& {\left[I_{2}\right]=\frac{[M]}{\rho_{0} h}}
\end{aligned}
$$

なお(26)式の構成は、グリーン関数と形状関数の積を 要素面で積分し重畳しており、板面を含む半無限空間に ついて境界要素法を適用したものと意味的に等価と解釈 できる。

\section{4. 解析例}

\section{1 解析対象と有限要素}

本章では以上の解析手法の具体的な適用例を提示する。 な扰对象とする板の形態は、上述のように相互作用のな い無限大バッフル内に設置された均一な平板であり、周 辺支持条件や平面形状は特に制限していない。ここでは、 手法の妥当性の検討を目的に、従来から解析対嘅として きた周辺固定長方形アルミニウム板の平面波画直入射 $\left(E_{i}=A B\left|p_{i}\right| 2 / 2 z_{0}\right)$ に対する透過損失を解析し、解析解 等と比較する。表 1 に解析対象の物性值を示してるる。

解析に用いた有限要素及び分割数も、既報8) 同様、 各節点に $(w, \partial w / \partial y, \partial w / \partial x)$ の 3 自由度を持つ長方形板曲 げ要素、10×6分割、即ち135自由度、を採用した。

4.2 比放射インピーダンスの具体的算定方法

(29)式を用い比放射インピーダンスを具体的に算定す るため、ここでは、有限要素法や境界要素法等で多用さ れるガウス積分を以下の方法で適用している。 
まず、 $e \neq e_{2}$ の場合には(29)式の積分へガウスの 2 点 法を直接適用する。次に $e=e_{2}$ の場合、皘分の際に $r=0$ の特異点の処置が必要となるため、

$$
\left\{\begin{array}{l}
x-x_{2}=r \cos \Theta \\
y-y_{2}=r \sin \Theta
\end{array}\right.
$$

の変数変換を施した後、ガウスの 3 点法を適用する。な お、この変数変換により(29)式中の $\left[I_{1}\right]$ は次のように変形 できる。

$$
\begin{array}{r}
{\left[I_{1}\right]=\left\{\sum_{e} \sum_{e=2}\left[S_{e}\right]^{T} \iint_{e}\left[N_{w}(x, y)_{e}\right]^{T}\left[I_{e_{2}}\right] d x d y\left[S_{e_{2}}\right]\right\}+} \\
\left.\left\{\sum_{e}\left[S_{e}\right]^{T}\right\} \int_{e}\left[N_{w}(x, y)_{e}\right]^{T}\left[J_{e}\right] d x d y\left[S_{e}\right]\right\}
\end{array}
$$

但し、

$$
\left[J_{e}\right]=\iint_{e}\left[N_{w}\left(r \cos \Theta+x_{2}, r \sin \Theta+y_{2}\right)_{e}\right] \mathrm{e}^{-i k r} d \Theta d r
$$

さらに、(32)式の算定にあたっては、次式のように図 3 の各象限 $v(v=1,2,3,4)$ 毎の積和を行っている。

$\left[J_{e}\right]=\sum_{v=1}^{4}\left[J_{v}\right]$

$\left[J_{v}\right]=\sum_{\kappa=1}^{3} \int_{r^{\prime}}^{r_{v^{\prime \prime}}} \int_{\Theta_{v^{\prime}}}^{\Theta_{v^{\prime \prime}}}\left[N_{w}\left(r \cos \Theta+x_{2}, r \sin \Theta+y_{2}\right)_{e}\right] \mathrm{e}^{-i k r} d \Theta d r$

積分領域 $\left(\left(r^{\prime}, \Theta^{\prime}\right) \sim\left(r^{\prime \prime}, \Theta^{\prime \prime}\right)\right)$ は、長方形要素の形状に よって異なる。これを要素長 $a, b$ と特異点 $\left(x_{2}, y_{2}\right)$ の関係毎

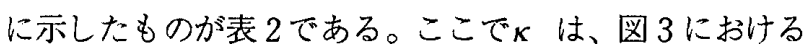
各象限の積分領域を、 $\Theta$ の始点または終点が座標軸上に 存在するか否かによって、「 $\kappa=1: \Theta の$ 始点及び終点とも

\section{表 1 解析対象（アルミニウム板）の物理定数}

Young's modulas mass density Poisson's ratio loss factor dimensions $\begin{array}{lllll}E\left[\mathrm{~N} / \mathrm{m}^{2}\right] & \rho\left[\mathrm{kg} / \mathrm{m}^{3}\right] & \sigma & \eta & A[\mathrm{~m}] B[\mathrm{~m}]\end{array} \quad h[\mathrm{~m}]$

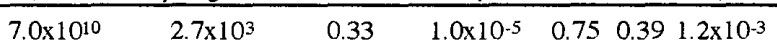

に座標軸上にある、 $\kappa=2: \Theta の$ 始点又は終点の一方か座標 軸上にある、 $\kappa=3: \Theta の$ 始点及び終点ともに座標軸上にな い、という各場合に忘し 3 種に分類する記号である。

この方法によれば、 $e \neq e_{2}$ の場合 4 点、 $e=e_{2}$ の場合 $108(=3 \times 3 \times 4 \times 3)$ )点における積和により積分を近似す ることになる。なお、今回のように分割パタンが規則的 な場合、要素形状が同一なため、全要素e に関する $\left[J_{e}\right]$ ( 及ひ $\left.J_{v}\right]$ ）が全て同一の值となる。

\section{3 結果及び考察}

今回の解析に用いた有限要素の要素長は、ほほ $4 \mathrm{kHz}$ の 音波長程度となっているため、本節では $1 \mathrm{kHz}$ 以下の領域 の解析を主眼としている。

4.3.1 固有值解析結果とモードの抽出

(6)式の固有值解析によって、既報8)と同一の、135個の $\omega_{n}$ 及び $\left\{\phi_{n}\right\}$ が得られた（表3）。これら全てのモードに 関する連成の組み合わせ数は9180組である。しかし本章 での解析の入射条件 (平面波垂直入射) の場合、幾何学 的に逆対称のモードの放射音圧は(3)式の分子が 0 となる ためその影響を無視でき、組み合わせから除外できる。

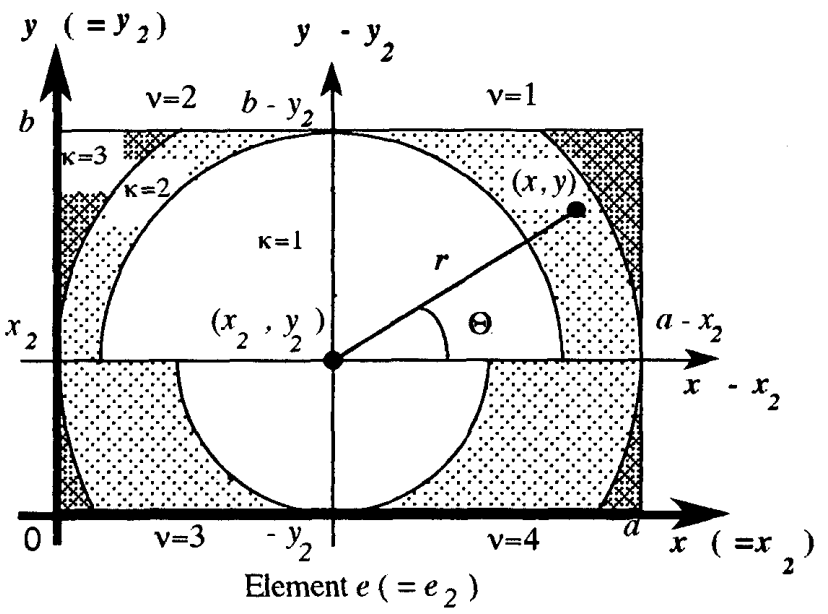

図3 $(x, y)$ 座標系から $(r, \Theta)$ 座標系への変換、

\begin{tabular}{|c|c|c|c|c|c|c|c|}
\hline & $v=1$ & $v=2$ & & $v=3$ & & $v=4$ & \\
\hline \multirow{6}{*}{$\begin{array}{l}r_{v}^{\prime} \\
r_{v} \\
\theta^{\prime \prime} \\
\theta_{v} \\
{ }_{v}\end{array}$} & $\frac{\left(\operatorname{lil} a-x_{2}\right.}{\left(\mathrm{F} F b-y_{2}\right)}$ & (IF $\left.x_{2} \geq b-y_{2}\right)$ & & $\left(\operatorname{lF} x_{2} \geq y_{2}\right)$ & & $\left(\right.$ IF $\left.a-x_{2} \geq y_{2}\right)$ & \\
\hline & $0 \quad b-y_{2}$ & $0 \quad b-y_{2}$ & $x_{2}$ & $\begin{array}{ll}0 & y_{2}\end{array}$ & $x_{2}$ & $0 \quad y_{2}$ & $a-x_{2}$ \\
\hline & $\sqrt{\left(a-x_{2}\right)^{2}+\left(b-y_{2}\right)^{2}}$ & $-y_{2}$ & $\sqrt{x_{2} 2+(b-y)^{2}}$ & $y_{2}$ & $\sqrt{x 2^{2}+y_{2}^{2}}$ & $a-x_{2}$ & $\sqrt{\left(a-x_{2}\right)^{2}+y_{2} 2^{2}}$ \\
\hline & $\cos ^{1} \frac{a-x_{2}}{r}$ & $\frac{\pi}{2} \pi-\sin ^{-1} \frac{b-y_{2}}{r}$ & $\pi-\sin ^{1} \frac{b-y_{2}}{r}$ & $\pi$ & $\pi+\cos ^{-1} \frac{x_{2}}{r}$ & $\frac{3 \pi}{2} \frac{3 \pi}{2}+\cos 1 \frac{y_{2}}{r}$ & $\frac{3 \pi}{2}+\cos ^{-1} \frac{y_{2}}{r}$ \\
\hline & $\frac{\pi}{2} \quad \sin ^{1} \frac{b-y_{2}}{r}$ & $\pi$ & $\pi-\cos ^{-1} \frac{x_{2}}{r}$ & $\frac{3 \pi}{2} \frac{3 \pi}{2} \cdot \cos ^{1} \frac{y_{2}}{r}$ & $\frac{3 \pi}{2}-\cos ^{-1} \frac{y_{2}}{r}$ & $2 \pi$ & $2 \pi-\cos ^{-1} \frac{a-x_{2}}{r}$ \\
\hline & (IF $\left.a-x_{2}<b-y_{2}\right)$ & $\left(\right.$ IF $\left.x_{2}<b-y_{2}\right)$ & & ( IF $x_{2}<y_{2}$ ) & & $\left(\right.$ (IF $\left.a-x_{2}<y_{2}\right)$ & \\
\hline$r_{v}^{\prime}$ & $0 \quad a-x_{2}$ & $0 \quad x_{2}$ & $b-y_{2}$ & $0 \quad x_{2}$ & $y_{2}$ & $a-x_{2}$ & $y_{2}$ \\
\hline$r_{v}$ & $\sqrt{\left(a-x_{2}\right)^{2}+\left(b-y_{2}^{12}\right.}$ & $b-y_{2}$ & $\sqrt{x_{2}^{2}+\left(b-y_{2}\right)^{2}}$ & $x_{2}$ & $\sqrt{x_{2}^{2}+y_{2}{ }^{2}}$ & $2-x_{2}$ & $\sqrt{\left(a-x_{2}\right)^{2}+y_{2}{ }^{2}}$ \\
\hline$\theta_{v}$ & $\cos ^{1} \frac{a-x_{2}}{r} \quad \sin ^{1} \frac{b-y_{2}}{r}$ & $\frac{\pi}{2}$ & $\frac{\pi}{2}+\cos ^{-1} \frac{b-y_{2}}{r}$ & $\pi \frac{\pi}{2}+\cos ^{-1} \frac{x_{2}}{r}$ & $\pi+\cos ^{1} \frac{x_{2}}{r}$ & $\frac{3 \pi}{2}$ & $\frac{3 \pi}{2}+\cos ^{-1} \frac{y_{2}}{r}$ \\
\hline$v$ & $\cos ^{1} \frac{a-x_{2}}{r}$ & $\pi-\cos ^{-1} \frac{x_{2}}{r}$ & & & & $-\cos ^{-1} \frac{a-r}{r}$ & $2 \pi-\cos ^{-1} \frac{a-x_{2}}{r}$ \\
\hline
\end{tabular}
音源及び受音点は $(x, y)$ 及び $\left(x_{2}, y_{2}\right)$ 、 vは象限、кは各象限にお㚈る領域の番号を示す

表2 (34)式の積分領域 
従って、 a priori に境界条件を設定し、逆対称モードを予 め除外しておく方法等も考えられるが、ここでは、より 沉用性の高い次のような数値的方法を適用した。

平板の振動では、低周波数からモードの出現順序をみ た場合、 $x, y$ 両方向共に対称な $(1,1)$ モードから出現する。 そこで、このモードによる(3)式分子の $\left\{\phi_{1}\right\}\{F\} \mid$ の値を基 準に、各モードの $\left|\left\{\phi_{n}\right\}\{F\}\right|$ の值が基準値の106倍以下の 場合、そのモードが振動及び音響放射へ与える影響を無 視できるものとした。今回の場合、この方法で98個のモ 一ドが除外され、表 3 の37個が抽出された。なおこれは、

表 3 解析に用いた37個のモードの

出現順序：No., 次数： $n$,及び周波数： $\mathrm{f}[\mathrm{Hz}]$

\begin{tabular}{rccccccccccc} 
No. & $n$ & $\mathrm{f}[\mathrm{Hz}]$ & No. & $n$ & $\mathrm{f}[\mathrm{Hz}]$ & No. & $n$ & $\mathrm{f}[\mathrm{Hz}]$ & No. & $n$ & $\mathrm{f}[\mathrm{Hz}]$ \\
\hline 1 & 1 & 48 & 11 & 36 & 599 & 21 & 73 & 1287 & 31 & 110 & 2395 \\
2 & 3 & 89 & 12 & 37 & 605 & 22 & 75 & 1297 & 32 & 111 & 2428 \\
3 & 8 & 177 & 13 & 39 & 632 & 23 & 77 & 1360 & 33 & 113 & 2455 \\
4 & 12 & 241 & 14 & 44 & 720 & 24 & 82 & 1433 & 34 & 115 & 2507 \\
5 & 14 & 266 & 15 & 47 & 788 & 25 & 85 & 1590 & 35 & 120 & 2610 \\
6 & 17 & 313 & 16 & 51 & 880 & 26 & 87 & 1602 & 36 & 121 & 2653 \\
7 & 18 & 328 & 17 & 52 & 913 & 27 & 88 & 1670 & 37 & 124 & 2728 \\
8 & 27 & 441 & 18 & 66 & 1134 & 28 & 92 & 1784 & & & \\
9 & 29 & 492 & 19 & 67 & 1155 & 29 & 103 & 2048 & & & \\
10 & 34 & 596 & 20 & 69 & 1217 & 30 & 107 & 2295 & & &
\end{tabular}
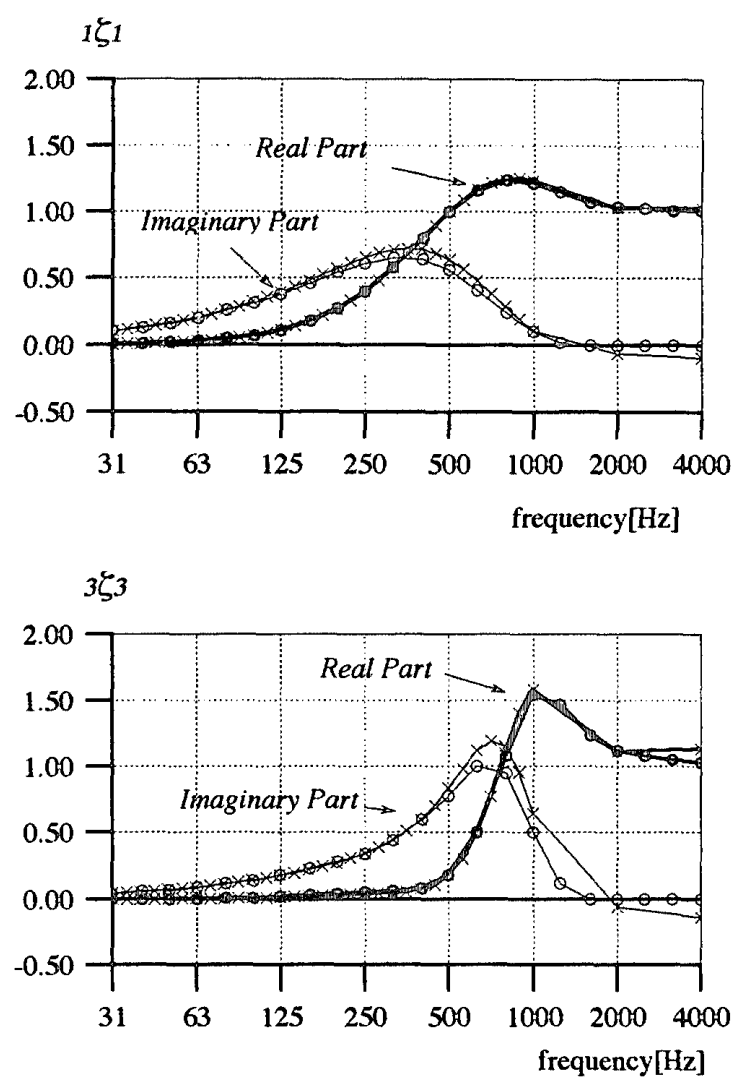

* $\operatorname{Re}$ \{本論の手法 $-\operatorname{Re}$ 解析的手法

* Im \{本論の手法 $\}$ - Im. \{ 解析的手法 $\}$

図4 比放射インピーダンス算定結果 (上段): ${ }_{1} \zeta_{1} 、$ (下段): ${ }_{3} \zeta_{3}$
既報8におけるモードベクトルのコンピュータによる次 数識別方法（モードチェッカと呼称していた）で抽出さ れた対称モードの個数と同一である。またこの手続きに より、モードの組み合わせ数は703組へと隇じられる。

\subsection{2 比放射インピーダンス算定結果}

4.2の方法を用い、前節で抽出された703組のモードに 関する比放射インピーダンスを求めた結果の一部を図 4、 5に示す。これらの結果の妥当性について、次の 2 面か ら検討している。

第一に、本論の手法によって得た值と田中3)4)による解 析的手法を用いて得られた值との比較である。但し、板 振動モードは $x, y \quad 2$ 次元方向の次数の組み合わせからな り、特に高次のモードでは用いる関数列や多項式近似の 方法により、その出現順序やモードシェイプの細部に若 干の相違が生じ得る。このため単に出現順序のみで照合 した場合、 $\left\{\phi_{n}\right\}$ と関数展開を用いた解析的手法で用いら れているモードシェイプは必ずしも一致するとは限らな い。そこで、モードシェイプが単純で形状としで近いと 推定される、1次及び3次のモードについて比較したも のか図 4 である。なお比較するモード相互のx,y 再方向の 次数の一致については、上記のモードチェッカによって 別途、確認している。

図 4 では本諭の手法による值を $1 / 6$ Oct.点毎に、解析的 手法による值を $1 / 3$ Oct.点毎に、それぞれ求めて比較して いるが、まず、 $\zeta_{1}$ に関し良好な一致が得られている。 また ${ }_{3} \zeta_{3}$ についても、值のピーク付近で若干の相違が見 られるものの、全般にわたって良好な近似が得られてい る。

続いて第二の検討を行う。理論的には $\zeta_{n}={ }_{n} \zeta_{m}$ が成 立する。以下これを比放射インピーダンスのモード間の 相反性 (reciprocity) と呼ふ。しかし(29)式ではこの点が明 確とは言えない。そこで、この比放射インピーダンスの モード間の相反性に着目し検討した結果の一例が図 5 で ある。第36次モードに関する場合にごくわずかな相違が 認められるものの、全般にわたり、互いに独立に求めら れた数值がよく一致し、比放射インピーダンスのモード 間の相反性が明瞭に出現している。また、各 ${ }_{m} \zeta_{n} と_{n} \zeta_{m}$ の実部と虚部に関し、ピアソンの積率相関係数学算定し たところ、14次以下のモードについては31Hz $4 \mathrm{kHz} の$ 全周波数領域でほぼ0.99、全てのモードに関する相関に ついても、1kHz以下の領域ではほぼ0.90以上の值が得ら れた。従って以上の結果を総合すれば、今回解析対象と した弾性板の比放射インピーダンス算定にあたり、(29) 式へ4.1節で示した方法を適用した場合、比放射インピー ダンスのモード間の相反性が成立しているものとみなせ よう。

\section{3 .3 透過損失解析結果}

前節の結果を踏まえ、本節の透過損失算定では、 $m=n$ 
$1 \xi 3,3 \zeta 1$

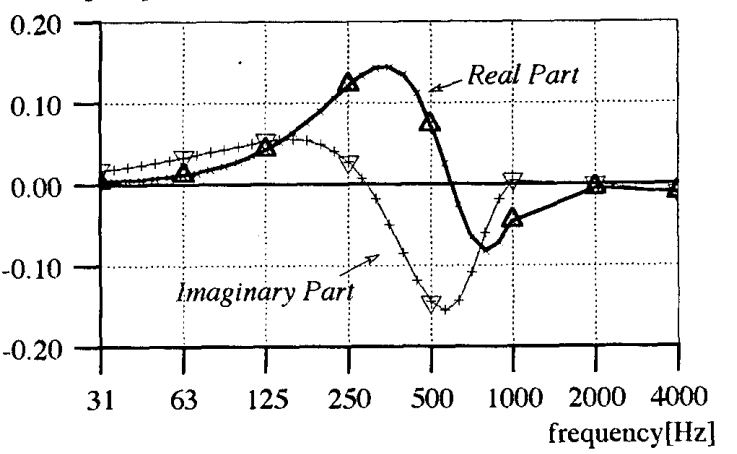

$-\operatorname{Re}\{1 \zeta 3\}+\operatorname{Im}\{1 \xi 3\} \Delta \operatorname{Re}\{3 \xi 1\} \nabla \operatorname{Im}\{3 \xi 1\}$

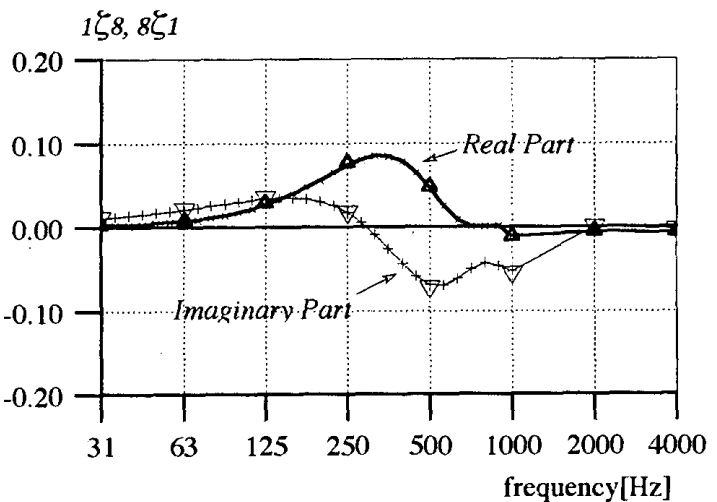

$-\operatorname{Re}\{1 \zeta 8\}+\operatorname{Im}\{1 \zeta 8\} \Delta \operatorname{Re}\{8 \zeta 1\} \nabla \operatorname{Im} .\{8 \zeta 1\}$

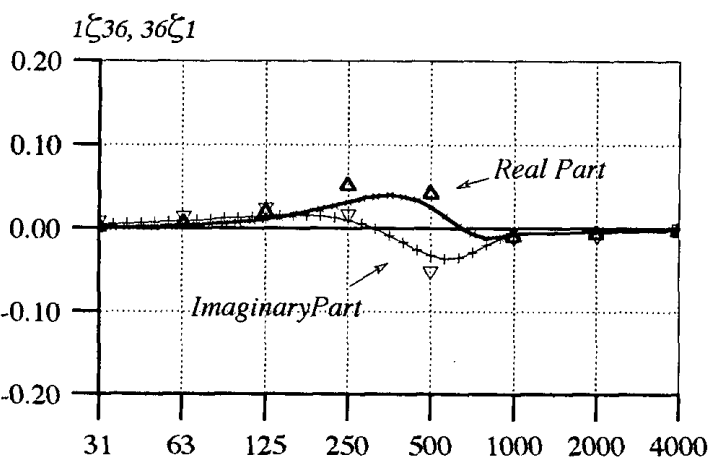

frequency[Hz]

$-\operatorname{Re}\{I \zeta 36\}+\operatorname{Im}\{1\} 36\} \Delta \operatorname{Re}\{36 \zeta\}\} \nabla \operatorname{Im}\{36 \zeta I\}$

図 5 比放射インピーダンスの モード間の相反性

(上段) ${ }_{1} \zeta_{3}$ と ${ }_{3} \zeta_{I}$ (中段) ${ }_{1} \zeta_{8}$ と ${ }_{8} \zeta_{I}$ (下段) ${ }_{1} \zeta_{36}$ と ${ }_{36}, \zeta_{1}$

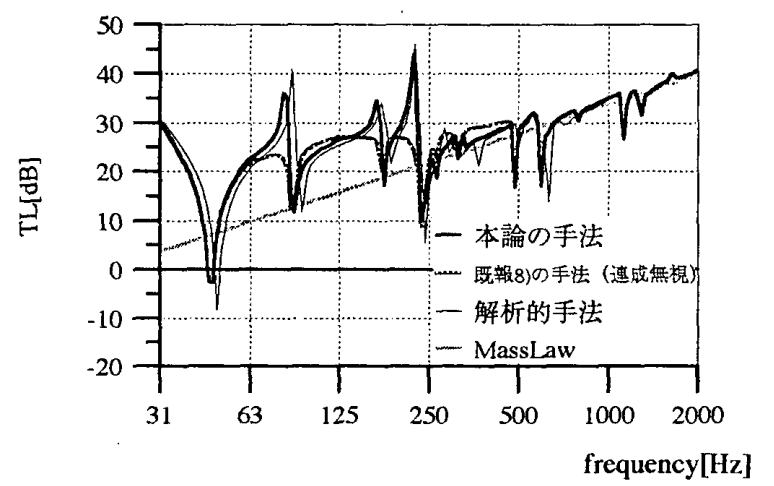

図 6 透過損失算定結果
の場合を除き、全体の半数の ${ }_{m} \zeta_{n}$ のみを求め、 ${ }_{n} \zeta_{m}={ }_{m} \zeta_{n}$ として適用した。こうして求めた透過損失值を、前述の 解析的手法による結果と比較して図6に示す。有限要素 解と解析解の間に共振周波数に関し若干の相違が認めら れるものの、全般に両者の一致は良好である。なお、周 辺固定板の共振周波数の解析解は得られておらず、また 解析的手法といえども有限要素法同様に最終的には有限 項からなる数値的な近似計算によって求められた値であ ることも考慮して、この相違については精密な実験との 比較や他の有限要素を適用する等さらに本手法の精度面 からの検討を重ねる必要があるものと思われる。但し今 回の解析結果では、モード間の連成を無視した従来の手 法8)で出現しなかった、「第1共振点を除いた低次の共振 点より僅か低い周波数で透過損失が非常に大きくなる」 2)籄所も算定されており、解析的手法による結果により 近い值が得られている。

以上のように、比放射インピーダンスの近似精度、そ のモード間の相反性、さらに透過損失算定精度の 3 点か ら検討した結果、それぞれ良好な結果が得られており、 本論で提示した各式並びに具体的算定方法の妥当性が示 されたものと結論できよう。

\section{5. 結}

無限大バッフル内に設置された屈曲振動板の音響入射 に対する振動・音響放射性状に関し、板面のみを有限要 素分割し、マトリクス演算により放射音エネルギーや比 放射インピーダンス、透過損失等を算定するための各式 の導出を行った。また、長方形アルミニウム板の透過損 失解析への応用例から、比放射インピーダンスの具体的 算定方法の提示と、本手法により得られる結果の妥当性 を示した。なお本手法は、相互作用のない無限大バッフ ルを挟む半無限空間を仮定することにより室形状の影響 を排除しているため、板の音響性状に焦点を絞った検討 に適し、また板要素のみを用いた有限要素解析により得 られる情報を活用することから、利用可能な自由度数を 板の解析へ集中できる点も特徵である。本手法によれば、 種々の複雑な周辺支持条件や形状の壁体の音響特性解析 も可能であり、現在、各種の検討を行っている。解析に は主に九州大学大型電算センターFACOM VP-2600を用 いた。

\section{謝辟}

本研究を進めるにあたり多大のご助言やご協力を頂い た、九州大学工学部建築学科の中村洋先生、藤本一寿先 生及び中村・藤本研究室の皆様に、深謝の意を表します。 注

本報は、文献No.20,21,22,23で発表した論文に加筆、修正を加えた ものである。 


\section{幾涪文献}

1) J. W. S. Rayleigh : The Theory of Sound second edition, Dover Publications, Vo.I Chapter X, Vol. II Chapter XV, 1945

2) 川井孝雄：一重壁の遮音機構の解析一円形平板の平面波垂直入 射、音鈝学会誌 29 巻 4 号、pp.186 198、1973年

3）田中 洪：矩形中空壁の垂直入射波に対する透過損失の解析、 音響学会誌 31 巻7号、pp.441 448、1975年

4) 田中 洪：矩形板の音製透過損失の算定に関する解析的研究、 東京工業大学学位論文、昭和 50 年

5）高橋大弐、古江義弘、松浦邦男：球面波入射による板振動・音 の透過、音響学会誌 35 巻6号、pp.314 321、1978年

6) 大鹤徹、坂田展甫、山岸豪敏：䅑やかな曲率を有する任意形 態遮音板の音製入射に対する応答解析、建築学会㻴境工学諭文 集 6 号、pp.35-42、1984年

7) T. Otsuru, H. Yamamoto, H. Yanagita : Sound Transmission Analysis by Computational Mechanics on Cylindrical Curved Plates, Proc. of Inter-Noise 88, Vol.1, pp.351 354, 1988

8) 大鶴 徹、山本秀樹：計算力学的手法による板の音響透過特性 解析、音製学会誌 44 巻 4 号、pp.293 299、1988年

9) A. Craggs : Sound transmission between enclosures - A study using plate and acoustic finite element - ACOUSTICA, Vol.35 No.2, pp89 98, 1976

10) J. Ramakrishnan, L. R. Koval : A finite element model for sound transmission through laminated composite plates, J. Sound Vib., 112 (3), pp.433 -446, 1987

11) 大鶴 徽、高崎 強、鋳山裕倫：板の形態とその遮音特性に 関する研究 一連成マトリクスと減衰マトリクスの構成一、建築 学会大会梗概集（東北）、pp.1423～1424、1991年

12) 加川幸夫 : 開領域問題のための有限/境界要素法、サイエン ス社、昭和 58 年
13) A. F. Seybert : APPLICATIONS OF THE BEM IN ACOUSTICS, NOISE-93 Proceedings, Vol.1, pp.255-262, 1993

14）阪上公博、杉本理恵、高栝大式、森本政之：有限要秋法 - 境界 要素法を用いた弾性平面板による反射音場解析、音䈉学会誌 48 巻11号、pp.786 793、1992年

15) 嘫津久一郎、宮本博、山田善之、川井忠彦 : 有限要素法ハンド ブックI、応用編 培風館、1983年

16) 戸川隼人：有限要素法による振動解析、サイエンス社、昭和57 年

17) O. C. Zienkiewicz（吉識雅夫、山田嘉昭監訳）：マトリクス有 限要素法、培風館、1975年

18) J. C. Sabonnadiére, J. L. Coulomb （神谷紀生訳）：有限要素法を 使ったCAD、サイエンス社、昭和63年

19) T. Otsuru, H. Yamamoto: Sound Transmission Analysis by Computational Mechanics using Characteristic Impedance of Mode Vectors, Proc. of Inter-Noise 90 Vol.1, pp.539 542, 1990

20) T. Otsuru : Sound Transmission Analysis by Computational Mechanics using Characteristic Impedance derived through a Finite Elemental Procedure, Proc. of Second International Congress on Recent Developments in Air- \& Structure- Borne Sound and Vibraton, Vol.1, pp.477 484, 1992

21）大鶴 徹：室と空気の振動/音響連成解析-その1 壁体の比放 射インビーダンス及び透過音エネルギーの計算力学的導出・、建 築学会九州支部研究報告、第33号、pp.157～160、1992年

22) 大鶴 徹：室と空気の振動／音響連成解析-その 2 遮音解析一 の適用…建築学会九州支部研究報告、第33号、pp.161 164、 1992年

23）大鶴 徹、大久保光次 : 弾性壁体と室空気の音響振動解析- の1解析手法の概要-、建築学会大会梗概集 (北陸)、pp.177 178、1992年 